\title{
ESCRAVOS VÃO À JUSTIÇA NA BAHIA SETECENTISTA
}

\author{
ALMEIDA, Kátia Lorena Novaes. Escravos e libertos nas minas do Rio \\ de Contas: Bahia, século XVIII. Salvador: Edufba, 2018. 346 p.
}

$P_{\text {ublicado em 2018, o mais recen- }}$ te livro da historiadora Kátia Lorena Novaes Almeida aborda a escravidão e a liberdade na região mineradora de Rio de Contas, na Chapada Diamantina da Bahia, sendo fruto de sua tese de doutoramento defendida junto ao Programa de Pós-Graduação em História da Universidade Federal da Bahia. Autora de um estudo anterior, lançado em 2012, no qual buscou compreender trajetórias sociais de egressos do cativeiro na referida região (Alforrias em Rio de Contas: Bahia, século XIX), Kátia Almeida explorou, desta feita, as leituras que escravos, libertos, senhores e advogados fizeram da escravidão e da alforria no termo de Rio de Contas, no século XVIII.

O recorte temporal adotado no livro tem início em 1724, ano em que o vice-rei Vasco Cezar de Menezes autorizou a criação da vila de Rio de Contas em função das descobertas auríferas no local e da necessidade de administrar e fiscalizar as riquezas dali provenientes, e se encerra em 1810, quando do desmembra- mento de parte significativa do território daquele termo para a formação da freguesia de Sant'Ana do Caetité. Partindo do pressuposto de que a alforria - assim como a resistência, a família e o compadrio de escravos, por exemplo - é fruto de relações estabelecidas entre senhores e seus cativos em contextos específicos, o estudo contribui de modo significativo para o preenchimento de uma lacuna na historiografia da escravidão no Brasil setecentista.

Para compreender as diversas leituras da alforria feitas por habitantes da vila de Rio de Contas, a autora dividiu seu livro em cinco capítulos. No primeiro, intitulado "Minas do Rio de Contas: governo dos povos, das almas e das minas", Almeida contextualiza as relações de cativeiro que se estabeleceram na região, destacando as atividades econômicas ali desenvolvidas, quais sejam: a mineração, a pecuária, a agricultura de subsistência e o pequeno comércio. Além disso, discute a utilização do trabalho escravo em tais atividades, bem como 
as medidas que visavam fomentar os interesses da Coroa portuguesa, desde a administração da Justiça à preocupação com os sacramentos católicos e, é claro, a exploração aurífera. O livro de Kátia Almeida reconstitui as histórias de seus personagens e os cenários em que estas se desenrolaram, realizando um exímio trabalho de história social da escravidão. Para tanto, a autora recorreu a uma vasta documentação primária, que engloba correspondências e relatórios de autoridades locais, consultas e despachos do Conselho Ultramarino, cartas régias, ofícios, solicitações de passaportes para escravos, mapas populacionais, livro de termo de vereação, ações de libelo cível, inventários, testamentos e escrituras.

A autora se vale do método de ligação nominativa de fontes, privilegia análises que consideram o protagonismo dos escravizados e libertos e busca escrever microbiografias de indivíduos "comuns", com o intuito de iluminar tanto aspectos das trajetórias de vida desses sujeitos quanto do mundo em que viveram e dos significados que atribuíam aos diversos acontecimentos em sua volta.

No segundo capítulo, "Escravidão no sertão: demografia, posse e vida familiar", a autora aborda o perfil demográfico dos escravizados no que se refere à origem, sexo, nação e cor/qualidade ao longo dos setecentos; analisa a distribuição da posse para perceber como e com que intensidade os proprietários fi- zeram uso dessa mão de obra, e tece reflexões sobre os laços familiares construídos pelos cativos na região. Como fontes para esses temas, foram utilizados inventários post mortem e a documentação gerada pelas listas de capitação da vila. Oferece, então, uma compreensão profunda das relações escravistas naquela região mineradora, lançando mão de métodos apropriados da história quantitativa, fornecendo minuciosas tabelas e gráficos e revelando redes familiares de pessoas escravizadas a partir das análises dos inventários dos proprietários escravistas de Rio de Contas.

Em "Demografia da alforria nas Minas do Rio de Contas", a pesquisadora traça o perfil dos alforriados na região utilizando uma série de 1.709 cartas de liberdade que alforriaram 1.822 indivíduos. Nesse capítulo, a autora mescla a história quantitativa com instigantes casos tão caros à história social. Um bom exemplo pode ser encontrado na sessão "Por que o senhor alforriava?", do Capítulo 3, na qual autora, de modo muito didático, tornando a leitura acessível e prazerosa aos mais diversos públicos - de acadêmicos a estudantes secundaristas e amantes da história em geral -, aborda o perfil dos senhores que alforriavam em Rio de Contas e apresenta uma carta de alforria particularmente rica: além de tratar da liberdade de uma mulher escravizada, o documento possibilita testemunharmos o reconhecimento da relação mantida entre senhores e 
suas escravas e da paternidade dos filhos. Na carta, Valentim Simões Moraes, em 1743, afirmou ser possuidor de "uma escrava por nome Antônia de nação mina, a qual para efeito de casar com ela e por ter quatro filhos da dita minha escrava e $[. .$.$] com Deus livrando-me da$ culpa de hoje para todo o sempre a hei por forra livre e liberta de todo o cativeiro" (p. 184). Valentim Moraes não foi o único proprietário de escravos a estabelecer relações com uma mulher escravizada de sua propriedade e reconhecer a paternidade da prole. Em Salvador, então chamada Cidade da Bahia, no mesmo século, em 1752, um destacado capitão de navio negreiro chamado Jacinto Gomes estabeleceu um relacionamento consensual com uma africana de nação mina, curiosamente também batizada como Antonia. Do testamento, seguem as palavras do capitão:

Declaro que sou solteiro e nunca fui casado sem embargo de que tenho dois filhos naturais havidos em uma escrava minha Antonia, um por nome Domingos e outro Manoel ambos mulatos, os quais são meus herdeiros forrados [...] e os declaro para haverem de $[\ldots]$ herdade meus bens o que diretamente lhe tocar por folha de partilhas [...]. Declaro que a preta Antonia e mais dois mulatinhos é forra por carta de liberdade que the dei, a quem também dei uma escrava por nome Joanna que há de constar escrito [...] que lhe passei, a qual também pos- sui uma moleca por nome Narciza, que também é sua. ${ }^{1}$

Além de Jacinto Gomes e Antonia Gomes, ainda na capitania da Bahia, na região do Recôncavo, outro caso semelhante aconteceu. Trata-se da relação entre o capitão Joaquim Manoel Barroso e Luzia, jeje, sua escrava e amásia, que fora por ele alforriada, da qual foram gerados filhos que também se tornaram legítimos herdeiros do capitão. ${ }^{2}$ A existência de casos similares ao de Valentim e Antonia na América Portuguesa setecentista não retira de forma alguma a novidade do caso trazido pela autora do livro aqui comentado. Pelo contrário, se constitui em oportunidade para estabelecer um diálogo entre as pesquisas e análises que relacionam gênero e escravidão, algo que poderia ter sido abordado por Kátia Lorena em diversas passagens do seu livro, como ao tratar da história de Bernardina, mina, alforriada por José Manoel de Araújo Alves junto com os quatro filhos do casal (p. 220). Se a relação de classe entre um senhor e seus escravizados é fun-

1 Análise mais completa da trajetória de Antonia Gomes pode ser conferida em: Raiza Cristina Canuta da Hora, "Escravidão, cor, gênero e mobilidade social: a trajetória de Antonia Gomes na cidade da Bahia setecentista", Interfaces Cientificas: Humanas e Sociais, v. 6, n. 2 (2017), pp.175-186.

2 Adriana Dantas Alves Reis, "As mulheres negras por cima: o caso de Luzia jeje: escravidão, família e mobilidade social: Bahia, c. 1780- c. 1830" (Tese de Doutorado, Universidade Federal Fluminense, 2010). 
damental para entendermos a história de Valentim e Antonia, bem como as outras duas relações inter-raciais citadas, não são menos importantes as relações de gênero ali presentes, para não se falar das raciais.

Utilizando cartas de liberdade registradas em livros de notas do tabelião, testamentos e registros de batismos como fontes, em " $\mathrm{E}$ como não pode usar a sua liberdade [...]: as experiências de liberdade nos diversos tipos de alforria", Almeida busca compreender os significados do registro da carta de alforria em cartório: o que representavam os diferentes tipos de alforria na experiências de liberdade dos indivíduos e as leituras que dela fizeram libertos e senhores? A autora identificou duas histórias que narram os obstáculos que escravos e senhores enfrentavam nas negociações para a alforria. Num caso, se evidencia a vulnerabilidade dos pequenos senhores ao negociar com seus cativos e, no outro, a dependência escrava do arbítrio de seus senhores que não honravam o combinado. A autora destaca que a interpretação da alforria apenas como um ato de doação voluntária do senhor ao seu escravo, sem considerar as condições nas quais foi efetuada, resulta na perspectiva apenas dos senhores e desconsidera que a submissão do escravo, que quase sempre transparece no documento da alforria, não significa passividade. A autora acrescenta que, ainda que outorgada por ato voluntário e legítimo do senhor, a alforria representou o sucesso dos esforços empreendidos tanto pelo escravo quanto, em muitos casos, por seus familiares ou sua rede de relações pessoais, uma vez que não se tratava, amiúde, de um projeto individual, mas coletivo. $\mathrm{E}$ foi esse empenho que tornou possível para alguns escravos concretizar suas experiências de liberdade.

Ainda nesse capítulo, a historiadora conclui que, em Rio de Contas, o registro da alforria em cartório era necessário porque o reconhecimento social da alforria pela comunidade não era suficiente, pois tratava-se de uma região onde o risco de reescravização se fazia presente, caracterizando o que se tem chamado de liberdade precária. Kátia Almeida também discute os tipos de alforria - gratuitas, onerosas, condicionais etc. - e seus múltiplos significados, apresentando dados em tabelas relacionando os tipos de alforria ao sexo do alforriado por década e uma seção dedicada exclusivamente ao preço pago pelas cartas de liberdade. A autora fornece assim informações de grande utilidade para os historiadores da escravidão e da liberdade.

No último capítulo, "A vulnerabilidade da alforria e o recurso à justiça", é aprofundado o tema da vulnerabilidade da alforria por meio da experiência de homens e mulheres que recorreram à Justiça para garantir seu direito à liberdade. Através de uma ação de justificação de 1734, Kátia Almeida traz à baila histórias de contendas judiciais como a de Ana Borges contra o seu senhor, 
Domingos Luís da Silva, que tentou reescravizá-la depois de Ana contabilizar quase 20 anos de liberdade! Sua história permite perceber como o poder privado dos senhores esbarrava no poder público para ponderar sobre liberdade e escravidão. Essas causas judiciais permitem refletir sobre a atuação dos escravos, libertos, senhores, advogados e juízes nelas envolvidos. A autora demonstra que não eram apenas os escravos que entraram na justiça contra seus senhores objetivando garantir sua liberdade, o contrário também acontecia: senhores contestavam a liberdade de homens, mulheres e crianças. Exemplo disso foi Luís de Moura Leite, que propôs uma ação de escravidão contra Margarida, filha de Florência Oliveira, crioula forra, objetivando anular a alforria que ele mesmo havia outorgado à mãe e à filha. A autora, apresentando vários casos pelo ângulo da micro-história, evidencia que senhores de Rio de Contas de pequenas posses recorriam à Justiça para reescravizar, pois não tinham poder pessoal suficiente para fazer justiça por seus próprios meios.

Desse modo, Kátia Almeida conclui que eram tênues os fios que separavam escravidão e liberdade, mas também mostra que os escravos recorreram à Justiça para se manterem ou se tornarem livres, não temendo contender com senhores de pouca monta, um tipo mais presente na vila do Rio de Contas, muitos deles, aliás, egressos do cativeiro. Mas a Justiça amiúde serviu aos interesses de senhores que buscavam manter ou reduzir pessoas em cativeiro. O fato é que a autora demonstra algo extraordinário: a Justiça no termo de Rio de Contas, desde o início dos setecentos, esteve ao alcance dos escravos, um aspecto da história da escravidão mais pesquisado para o século seguinte, sobretudo sua segunda metade.

A pesquisa aprofundada em arquivos diversos e em variadas fontes documentais, a maioria inédita, aliada ao diálogo com uma bibliografia acertada, o uso de métodos da história demográfica e da história social, associados a uma narrativa fluida, tornam o livro aqui resenhado uma valiosa contribuição para a historiografia da escravidão e da liberdade no Brasil, tornando-se leitura necessária para os cursos de história do Brasil colonial, com destaque para a capitania da Bahia.

\footnotetext{
Raiza Cristina Canuta da Hora raizacanuta@outlook.com Universidade do Estado da Bahia
} 
338 Afro-Ásia, 59 (2019), 333-338 